tion that has induced patients to apply for the frigorific application afresh, may have proceeded from the presence of this inert mass of dead cancer-cells. I should be sorry, however, to think that the absorption of these never talies place, because in a voltuminous congeries of cells it were difficult to unclerstand how the cold conld rench the inner surface of the mass without the absorption of the more superficial layers having previously taken place after the extinction of the life of the cells constituting them; unless, indeed, the layers of dead cells were to form so good a conductor as scarcely to resist its passage. But in their living state, the tumour in which they are interspersed is so dense and so little intermixed with bloodressels, as to form a substance easily permeable by cold-as easly, perhaps, as cystic tumours are, the fluid contents of which I hare congealed in applying cold to them, as an anresthetic, previous to their excision.

If it be objected to the cases which I have now related that they do not furmish satisfactory evidence that cancer is completely curable by cold, they show, at least, that it will produce much more benefit in this disease than any other remedy. If an unequirocal cancerous tumour subjected to this treatment, instead of increasing in size, gradually decreases, while the patient becomes free from pain, (excepting such uneasiness as a mass of dead cancer-cells might excite, ) and the general health improres, - if no glandular enlargement takes place in the armpit, or extension of the disease to any other part appears, and if this condition continues without change for a long period, it is surely a very satisfactory change in the patient's condition. I question much if it be possible entirely to remore the hardness in the majority of such cases, but this hardness is no proof of the presence of malignant affection, and no source of inconvenience to the patient. What other remedy yet employed in cancer will effect as much? Too many of the measures employed as remedies only precipitate the unfortunate patient's fate.

Before concluding this paper, I must advert to a statement which appeared some time ago in a medical journal, that a patient had been serionsly injured by a prolonged application of ice to her cancerous breast of upwards of twenty-four hours. As everyone has not yet learned the essential difference between the application of ice and congelation in disease, it may be advisable now briefly to point it out; and as the subduing of the infiammation usually accompanying cancer is one of the oljects in using either of these methods of treatment, it may simplify the matter to speak of this difference as respects their use in preventing or removing the inflammation after wounds or other mechanical injuries. Ice, or a temperature of $32^{\circ} \mathrm{Fahr}$, acts as minor degrees of cold do, in lessening the increased vascular action which accompanies (if it does not constitute the chief element of) the morbid condition called inflammation; but congelation, by causing a temporary suspension of the circulation and sensibility of a part, does this and a great deal more. It effects such a change in the vital actions of the part, perhaps by removing for a time the tonicity of the small arteries, as not only immediately to arrest inflammation, but to render the part unsusceptible of this condition for sometime afterwards. If this suspension of vitality be of short duration, there is not the least hazard of the part being permanently injured, and when congelation is purposely effected by a powerful frigorific, its duration and extent can be exactly limited. But if it should happen that owing to a debilitated state of the body, or other cireumstances, a prolonged application of ice should at length congeal the part, as the surgeon may not be aware of this unintended effect until after it has lasted for a long time, (as has happened in applying ice to gun-shot wounds and in strangulated hernia,) much injury may be the consequence. Fortunately, the aching usually caused by a continued application of ice is a preventive of such mischief, and another reason why it has been so little employed in surgery.

Upper Gloucester-place, Dorset-square, April, 1854.

P.S. - Since the above article was forwarded to the office of THE LANCET, on the 10th ult., Dr. Hardy has published a proposal similar to that contained in the note to the first paragraph, in the Dublin Medical Press of the 19th; but a stream of artificially cooled air was suggested as a substitute for other refrigerating means in the introduction to my collected essays on Congelation, published last year. Within this short period, likewise, Dr. Snow, who I believe is reckoned an authority on the subject of general anæesthesia, and who is much employed as a chloroformer, has, naturally enough, thought fit to attack its rival-local anæsthesia from cold-in a paper read before the Medical Society of London, and reported in the last number of THE LANCET. Notwithstanding the fact, not unknown to his hearers, that intense cold has already been extensively em. ployed for this purpose by some of the most eminent surgeons of the day, he indulges them with the recital of some hypothetical notions upon its itpplicability! Then Dr. Snow spoke of the great pain procinced by a frigorific mixture applied to his hand, he must have forgotten that both hands and feet often become benumbed in very cold weather without any preceding pain. Complete anesthesia to the small extent he speaks of, may be produced by cold, properly applied, with scarcely the slightest nneasy sensation; and when the circulation is quite arrested by cold, the smarting or tingling does not exceed that produced by mustard, and is nerer complained of by the patient. It is much less disagreeable to him than the sense of suffocation which accompanies, and the headache and sickness that follow, the exhibition of chloroform; to say nothing of his dread of losing consciousness and life.

I may probably, on some future occasion, notice certain other statements in Dr. Snow's paper; but I cannot advert to them at all without expressing surprise, that a practitioner, who has himself experienced all the horrors attendant on cansing death by chloroform, should still talk of employing it on the most trifling occasions. The case of death from chloroform, which has just occurred in France, and in the hands of so careful a surgeon as M. Richard, will, it may be hoped, be anongst the last; for strely a recourse to chloroform in preference to cold must very soon be confined to the comparatively small number of operations which involve the incision of deep-seated and sensitive parts; and even in these (as I have explained in my late pamphlet on the subject) a combination of cold with chloroform would render the exhibition of a large close of the latter unnecessary, while it would very much promote the healing of the wound.

\section{ON THE USE OF THE SCOOP IN LITHOTOMY.}

\section{BY SAMUEL SOLLY, EsQ, F.R.S.}

I TROUBLE the readers of THE LANCET with a few observations, from my own personal experience, on the value of the scoop in lith tomy. I am induced to do this from finding, in a recent excellent work on Operative Surgery, from the perusal of which I have derived much satisfaction, the following observation:-

"I do not recollect to have seen an instrument called a scoop, which is invariably found in lithotomy cases, called into aseful requisition.

I should be sorry if this remark should lead young surgeons to reject from their lithotomy instruments what I have frequently found a most valuable adjunct.

On Saturday last, when performing the operation of lithotomy in the country, I should have had extreme difficulty in extracting the stone if I had not been provided with the scoop. The stone, in this case, was lodged at the fundus of the bladder, the coats of which had contracted so forcibly round it that the forceps could not seize it firmly. When I found this difficulty in the extraction, I inserted the forefinger of my left hand into the bladder, and fixing the stone with it, passed the scoop with the other hand carefully between the mucous membrane and the stone. My patient was only twelre years old, but he had suffered with symptoms of stone from infancy; the mucous membrane was diseased, and therefore it requircd great care in securing the stone to avoid laceration of the walls of the bladder, to which they would have been liable under a perseverance in the use of the forceps. The stone, which was firmly adherent to the bladder, was thus safely extracted, and the time occupied in the operation was not much extended beyond the usual period.

As the great test of an operator is to be armed at all points, I would, while avoiding a needless accumulation of similar tools, be carefully provided to meet any casualty.

St. Helen's-place, City, May, 1854.

\section{THE SANITARY CONDITIONS 'OF LIGHT AND EPIDEMIC CHOLERA.}

By WILLIAM JOHN THOMAS, Esq., M.R.C.S., Kirkdale.

I PERCEIVE, from the perusal of THE LANCET, that an Egyptian darkness still defies the efforts of the medical philosopher to ascertain the causes of Asiatic cholera. It does not appear to me that we have made much progress in our attempts, since 1832, to define the origin of the pestilence. We are told it arises from miasmata, and that draining will remove the cause of the cholera; and yet the pestilence has assumed its most vivid form in the burning desert, where no 